\title{
TOURISM INFORMATION PROVIDERS IN LATVIA: DEVELOPMENT AND CHALLENGES
}

\section{Tūrisma informācijas sniedzēji Latvijā: attīstība un izaicinājumi}

\author{
Daina Vinklere \\ Turība University, Faculty of International Tourism \\ Daina.Vinklere@turiba.Iv
}

\begin{abstract}
The tourism information system uniting tourism information providers is one of the important players within the tourism industry both for destination development and for tourists. Since the first tourism information providers in Latvia started operations in 1994 it has been important to evaluate the development of this sector of the overall tourism industry. Therefore, the objective of this study is to analyse the achievements and challenges in the development of tourism information providers as part of the tourism information system in Latvia after 1991. For the purposes of reaching the objective of this paper, analysis and interviews with experienced managers of tourism information centres were used as the main research methods. The paper reveals that significant progress has been achieved in this area and tourism information providers have become important players for tourism development in Latvia at all levels - municipal, regional and national.
\end{abstract}

Keywords: tourism development, tourism information, tourism information centres, tourism information providers

\section{Introduction}

Significant changes in all areas of development have taken place in Latvia since 1991. However, the tourism information system is among those which was built completely from scratch. After the initial activities in the area of tourism information in Rucava, then part of the Liepāja region, it was only in 1994 that permanent tourism information centres were established in four municipalities of Latvia - the cities of Salacgrīva, Tukums, Jūrmala and Limbaži. Taking into account the sufficient duration of their operation: 25 years, it is essential to summarise and assess the results of the development and operation of the tourism information system, since they are of interest to all parties involved - tourism information providers, state institutions and entrepreneurs engaged in the tourism industry.

According to the explanation by Dimitrios Buhalis, tourism information centres (TICs) provide information and reservations for destinations and tourism companies. Operated by local, regional or national organisations, they aim to facilitate the visits of consumers and to assist organisations in implementing their policies, by increasing tourist length of stay and expenditure (Jafary 2000).

In Latvia, the forms and the key operational conditions for tourism information providers are governed by the Tourism Law. The current edition of the Tourism Law defines three categories of tourism information providers - a tourism information centre, a tourism information point and a tourism information stand (Tourism Law 1998). 
The Tourism Law also establishes the functions of the government and municipalities on the issues of tourism information providers. Municipalities shall: determine the prospects of tourism; provide measures for the provision of comprehensive and precise information in Latvia and foreign countries on tourism opportunities; participate in the development and financing of tourism information centres, points and stands (Tourism Law 1998).

Since the guaranteeing of operations of tourism information providers lies within the scope of municipal responsibilities, municipalities are those, which establish the legal status, operational conditions and specific functions of any particular tourism information provider. The specific situation in Latvia requires that the functions of tourism information centres in the country are significantly broader than elsewhere. The main directions for the activities of most TICs include collection, summarising and systematisation of information, providing of information to tourists, the organisation and conducting of marketing of a territory, organising of co-operation with entrepreneurs and promotion of the tourism business, co-operation with local authorities and their experts for the purposes of developing local tourism, addressing the issues of professionalism and education (Lattūrinfo 2014). Therefore, tourism information centres in their respective municipalities largely work also as destination management organisations (DMOs). One of the definitions provided by Inskeep in 1991 says that the DMO assumes the destination's central management functions, namely, strategic planning and destination development as well as product development and marketing (Pechlaner and Fuchs 2002).

The respective areas, particularly with regard to the operational specifics of tourism information providers have not been analysed often in a scientific research context. However, some authors have addressed, for instance, the topic of the role and responsibility of destination management organisations and tourism information providers in promoting tourism information in the online environment (Assenova et al. 2018) and the issues related to the financing of tourism information services in Poland and Hungary (Mayer and Pawlicz 2010). A few publications in the media and individual professional publications on related problems of TIPs (Smuškova 2017) have been devoted to this issue in Latvia. Several studies have also been conducted as part of the graduation papers of students at higher education institutions. The objective of this study is to assess the most significant aspects of the activities of tourism information providers over the course of 25 years. The research questions include: 1) What have been the main challenges for the operation of tourism information providers? 2) What are the main success stories and their contribution to the tourism industry of Latvia and to regional development from the perspective of the veteran managers of the tourism information centres?

\section{Data and Methods}

The existing study has been implemented in 2019 and aims to sum up and analyse the development of the tourism information system in Latvia since 1991. 
Qualitative research methods were used and included analysis of documents and regulations, as well as the conducting of eight semi-structured interviews with current and former managers of municipal tourism information centres - experts who have worked in the field for at least 13 years (i.e. more than a half of the research period) in at least two time-periods singled out in the study (see Table 1). This kind of selection of respondents ensures that their personal experience allows them to identify and compare the achievements, problematic issues and gains of the tourism information provider system over a longer period of time. The interviews dealt with four areas: the most significant events which have affected the formation and development of the tourism information provider network; the key challenges in the course of the period from 1994 to 2019; the main achievements in this area of tourism and the most significant gains of the operation of tourism information providers at the municipal, regional, national and international levels. Content analysis method was used for the interpretation of results of interviews.

Table 1. The most significant events, which affected the development of the tourism information system of Latvia

\begin{tabular}{|c|c|}
\hline Year & Event \\
\hline 1994 & The first four permanent tourist information centres commence their operation \\
\hline 1994 & $\begin{array}{l}\text { The first professionally trained tourism information centre employees graduate Rīga } \\
\text { School of Tourism }\end{array}$ \\
\hline 1996 & Latvian Association of Tourism Information Organisations LATTŪRINFO founded \\
\hline 1998 & $\begin{array}{l}\text { The Tourism Law legally defines the status of a tourism information provider } \\
\text { establishing their responsibilities at the national and municipal levels }\end{array}$ \\
\hline 1999 & $\begin{array}{l}\text { The first tourism information office abroad - Baltic Tourism Information Centre } \\
\text { (BTIC) - commences its work in Munster. In } 2003 \text { it was moved to Berlin. Offices of } \\
\text { the Latvian Tourism and Development Agency/Baltic Tourism Information were } \\
\text { later opened in Helsinki, Moscow and London }\end{array}$ \\
\hline 2001 & $\begin{array}{l}\text { The national tourism information provider standard LVS 200-7 was developed and } \\
\text { adopted }\end{array}$ \\
\hline $2001-2003$ & $\begin{array}{l}\text { State investment project Development of Latvian tourism information centre network } \\
\text { implemented }\end{array}$ \\
\hline 2002 & $\begin{array}{l}\text { LATTÜRINFO becomes a member of the European Union of Tourism Officers } \\
\text { (EUTO) }\end{array}$ \\
\hline 2004 & The Central Latvian Tourism Information Centre opened in Rīga (disbanded later) \\
\hline 2004 & $\begin{array}{l}\text { Professional standards for a tourism information consultant were developed. The } \\
\text { profession of a Tourism Information Consultant was included in the Latvian } \\
\text { professional classification registry }\end{array}$ \\
\hline 2009 & $\begin{array}{l}\text { Territorial restructuring of tourism information providers in compliance with the } \\
\text { administrative-territorial reform of Latvia }\end{array}$ \\
\hline 2012 & $\begin{array}{l}\text { Latvian tourism information centres commence their accession to the Latvian } \\
\text { tourism service quality system "Q-Latvia" }\end{array}$ \\
\hline 2013 & $\begin{array}{l}\text { The organisation of the annual Latvian tourism information fair events commenced } \\
\text { in various regions of Latvia targeted at boosting travel within the country, } \\
\text { particularly, during the so-called off-season. }\end{array}$ \\
\hline 2014 & LATTŪRINFO publishes its Handbook for tourism information providers \\
\hline 2017 & $\begin{array}{l}\text { Co-operation with the Latvian Society of Lawyers, outlining and specifying positions } \\
\text { and discussing regulations concerning the various sectors of the tourism industry, }\end{array}$ \\
\hline
\end{tabular}




\begin{tabular}{|c|l|}
\hline Year & \multicolumn{1}{c|}{ Event } \\
\hline 2019 & particularly, with respect to the development of the industry in the regions of Latvia. \\
\hline $\begin{array}{l}\text { Internal industry discussions as well as discussions in the Saeima on the amendments } \\
\text { to the Tourism Law regarding restrictions on the services of TICs related to unfair } \\
\text { competition in the public and private sectors. }\end{array}$ \\
\hline
\end{tabular}

\section{Results}

The quantitative dynamics represent one of the most vivid objective indicators of the development of the tourism information provider system. Until 2008 the number of tourism information providers grew quite significantly - from 4 in 1994 to 92 in 2008 (Donina et al. 2018) and as part of this study, at around 130 in 2018.

Analysis of the documents of the Latvian Association of Tourism Information Organisations LATTŪRINFO was performed as well as on the facts outlined during the interviews, and revealed a number of significant events, which affected the tourism information provider system. These events are chronologically summarised in Table 1.

Summing up the most significant events affecting the tourism information provider system, one can conclude that they can be divided into three different periods. The first one was concluded in 2001 by the establishment of the status by the Tourism Law and the creation of the national standard for tourism information providers, which eliminated uncertainties on the key issues as to who was considered as a tourism information provider, their categories and sources of financing. The next period lasted until the administrative-territorial reform commenced in 2009, which significantly affected the location and operation of the tourism information provider network and therefore initiated the third distinctive period in the activities of tourism information providers.

Based on the views expressed by the persons interviewed, the main challenges related to each period, which are undoubtedly linked with activities and events performed during each particular period, have been recorded, summarised, grouped and reflected in Table 2.

Some experts have noted the challenges, which in their estimation have been topical throughout the period of operation of the tourism information providers: different legal status and funding of tourism information providers, which affects their operation and co-operation activities, the lack of a single national supervisory institution the role of which is partially fulfilled by LATTÜRINFO; the prolonged uncertainty on the issue of certification of tour guides; the fact that the development of tourism in municipalities is largely based on the enthusiasm of the employees of tourism information providers which can eventually decrease and affect negatively the results of their work.

In assessing the accomplishments of the tourism information provider system as a whole during the defined period, experts have singled out the following: 1) the commencement of operations of tourism information centres under conditions of limited support; amendments to the Tourism Law on the implementation of activities of tourism information providers; the development of a tourism information provider 
standard; the establishment of the professional association LATTÜRINFO uniting and representing the industry interests; the creation of a real co-operation network of tourism information providers; the establishment of a centralised tourism information provider in the centre of Riga, however short-term it might have been, the establishment of the joint tourism information industry day tradition.

Assessing the results of tourism information providers at various levels, the respondents provided multi-fold answers., which can be divided into several individual sections. The respondents pointed to the following gains resulting from the activities of tourism information providers in Latvia:

Table 2. The key challenges for the providers of tourism information in Latvia during various periods

\begin{tabular}{|c|c|c|}
\hline 1994- 2001 & $2002-2008$ & $2009-2018$ \\
\hline $\begin{array}{l}\begin{array}{l}\text { The limited } \\
\text { responsible }\end{array} \\
\text { support by } \\
\text { institutions } \\
\text { information } \\
\text { established by to providers } \\
\text { enthusiasts }\end{array}$ & $\begin{array}{l}\text { Successful implementation of } \\
\text { investment projects designed } \\
\text { for the development of the } \\
\text { national tourism information } \\
\text { system }\end{array}$ & $\begin{array}{l}\text { Territorial restructuring of the } \\
\text { tourism information providers in } \\
\text { compliance with the } \\
\text { administrative-territorial reform } \\
\text { of Latvia }\end{array}$ \\
\hline $\begin{array}{l}\text { The lack of understanding in } \\
\text { most of the municipalities on } \\
\text { the importance of the tourism } \\
\text { information system and as a } \\
\text { consequence: insufficient } \\
\text { financing and the lack of } \\
\text { conformable support and } \\
\text { provision }\end{array}$ & $\begin{array}{l}\text { Commencement of the process } \\
\text { of certification of tourism } \\
\text { information providers in } \\
\text { compliance with the national } \\
\text { standard of Latvia, later: Q- } \\
\text { Latvia, the quality system in } \\
\text { tourism }\end{array}$ & $\begin{array}{l}\text { Work-related organisational } \\
\text { changes and the diversification } \\
\text { of functions of tourism } \\
\text { information providers brought by } \\
\text { the changes in the legal status of } \\
\text { TIS }\end{array}$ \\
\hline $\begin{array}{l}\text { Unclear legal status of } \\
\text { Tourism information centres } \\
\text { and their means of financing } \\
\text { up until the amendments to } \\
\text { the Tourism Law } \\
\text { implemented in 1998 }\end{array}$ & $\begin{array}{l}\text { Substantial increase of } \\
\text { workload and its } \\
\text { diversification related to active } \\
\text { participation in the available } \\
\text { EU projects }\end{array}$ & $\begin{array}{l}\text { Active engagement in the EU } \\
\text { supported projects targeted at the } \\
\text { development of tourism in } \\
\text { municipalities and regions }\end{array}$ \\
\hline $\begin{array}{l}\text { The lack of unified quality } \\
\text { standards }\end{array}$ & $\begin{array}{l}\text { Opportunities for significantly } \\
\text { improving the material } \\
\text { provisions of tourism } \\
\text { information providers in the } \\
\text { framework of the EU } \\
\text { supported projects }\end{array}$ & $\begin{array}{l}\text { New challenges related to the } \\
\text { changes in the use of means and } \\
\text { methods of marketing (e- } \\
\text { environment, social networks, } \\
\text { etc.) }\end{array}$ \\
\hline $\begin{array}{l}\text { Inadequate quality of work of } \\
\text { many tourism information } \\
\text { providers. }\end{array}$ & $\begin{array}{l}\text { Regional co-operation and } \\
\text { activities in the framework of } \\
\text { established and/or strengthened } \\
\text { regional tourism associations }\end{array}$ & $\begin{array}{l}\text { Search for new forms of co- } \\
\text { operation in tourism with tourism } \\
\text { entrepreneurs driven by the } \\
\text { sharing economy }\end{array}$ \\
\hline $\begin{array}{l}\text { Insufficient understanding by } \\
\text { the general public on the } \\
\text { input of municipalities in } \\
\text { tourism and the financing of } \\
\text { tourism information } \\
\text { providers }\end{array}$ & $\begin{array}{l}\text { Engagement in international } \\
\text { experience exchange activities } \\
\text { in the framework of the } \\
\text { common European Union of } \\
\text { Tourism Officers (EUTO) } \\
\text { projects }\end{array}$ & $\begin{array}{l}\text { Raising the legal issue regarding } \\
\text { the operations of tourism } \\
\text { companies, municipalities, TIS } \\
\text { and the ensuring of fair } \\
\text { competition as well as changes in } \\
\text { the area of package tourism } \\
\text { services }\end{array}$ \\
\hline
\end{tabular}




\begin{tabular}{|c|c|c|}
\hline 1994- 2001 & $2002-2008$ & $2009-2018$ \\
\hline $\begin{array}{l}\text { Limited access to external } \\
\text { (European Union) funding } \\
\text { for the development of } \\
\text { tourism information centres }\end{array}$ & $\begin{array}{l}\text { The entry of newly qualified } \\
\text { experts in the tourism } \\
\text { information system who had } \\
\text { acquired higher education in } \\
\text { the area of tourism }\end{array}$ & $\begin{array}{l}\text { Possible changes in the } \\
\text { framework of the planned } \\
\text { administrative-territorial reform }\end{array}$ \\
\hline
\end{tabular}

1) At the municipal level: an institutionalised system of promoting tourism development has been created ( 3 interviewees); an institution for tourism information providers has been created and operates as a "business card" for each respective municipality serving guests in several foreign languages; tourism information providers have been recognised as important promoters of the development of their respective territories; tourism-related entrepreneurial activity has been activated significantly and a business community has been created (5); an image/brand of a municipality as a tourism destination has been formed and its public recognition has been promoted (8); advertising of local businesses has been performed and the promotion of local production and sales of locally made souvenirs has been promoted; public tourism infrastructure has been improved; a comprehensive tourism database in several languages has been created (2); the development of tourism has been promoted in general (2); municipalities have gained a better understanding and recognition of tourism as a branch of the economy;

2) At the regional level: a tourism development-oriented institutional system has been created; co-operation among various parties interested in the development of regional tourism has been provided, including co-operation in the framework of the regional tourism association (4); a common regional identity has been created and its recognisability has been promoted (4); thanks to the professional and active work of TICs, municipalities have understood and are supportive of joint regional activities in the area of tourism;

3) At the national level: regional and parish level a tourism destination image has been formed and is being promoted (2); regional tourism associations and LATTÜRINFO are good co-operation partners for the Latvian Investment and Development Agency in implementing joint goals and activities (2); TICs are the most knowledgeable co-operation partners for other professional tourism organisations in addressing topical issues and forming of market offers in their respective territories; the tourism service databases created by tourism information providers are used by various state institutions (e.g. The State Revenue Service) for their own direct purposes;

4) At the international level: co-operation partners have been found and many international projects have been successfully implemented (2); the image and recognition of Latvia as a multi-faceted tourism destination and a trustworthy cooperation partner has been improved (2); LATTŪRINFO and tourism information providers have proven their professionalism in their international activities, thus raising the status of the industry and Latvia in general (2); international journalists and 
bloggers consider tourism information centres as a quality source of information and co-operation partners; the activities of TICs have on many occasions ensured the attraction of specific project-based co-operation partners for several local companies.

\section{Conclusion}

The study results lead to a number of conclusions, which are listed below.

After 1991 the tourism information system and the network of tourism information providers in Latvia was formed completely from scratch and, as the result of 25 years of operation and thanks to the support by municipalities, has become a crucial player for the development of tourism in various regions of Latvia. The support of state institutions has not been particularly intense. However, the development of the system was substantially boosted by providing an orderly regulatory basis (the status of tourism information providers, sources of financing, quality standards) as well as by the implementation of the state investment project for the development of the TIC network in Latvia. The availability of the European Union funding for the promotion of tourism and the development of the digital environment substantially affected the workload and functions of tourism information providers. According to the most experienced Latvian heads of tourism information centres, the operation of the tourism information system has provided significant input in the development of tourism and the respective territories at all levels: municipal, regional, national and international.

Assessing the results of the study in the context of future developments, it should be stressed that they reflect the development of the system as stated in various documents and the subjective opinions of long-term managers of tourism information centres. In future, they should be supplemented with specific indicators as well as the assessments of persons who joined the system at a later stage and also by the opinions of other parties: municipalities, state institutions, regional and professional tourism associations.

\section{Kopsavilkums}

Tūrisma informācijas sniedzēju tīkls Latvijā 25 darbības gados ir attīstījies gan kvantitatīvi, gan kvalitatīvi, saņemot pašvaldību un valsts atbalstu, kā arī lielā mērā baudot tajos strādājošo darbinieku ieinteresētību. Ilglaicīgi stādājošo Tūrisma informācijas centru vadītāju vērtējumā Tūrisma informācijas sniedzēji ir devuši būtisku ieguldījumu ne tikai tūrisma attīstībā, bet arī kopējā teritoriju attīstības un atpazīstamības veicināšanā pašvaldību, regiionu, nacionālajā un arī starptautiskajā līmenī.

\section{References}

Assenova, M., Marinov V. and Petrov, E. (2018). Destination management systems in Bulgaria: the current situation and challenges. Annual of Sofia University "St. Kliment Ohridski", Faculty of Geology and geography, Book 2-Geography, 111, 1-32.

Cabinet of Ministers of the Republic of Latvia (1998). Tourism Law. Riga, Latvia: Saeima of the Republic of Latvia.

Doniņa, A., Rozīte, M. and Vinklere, D. (2018). Latvia. In: Hospitality and Tourism in Transitioning Central and Eastern Europe. A Comparative Analysis. Vodenska, M. (ed.) Cambridge Scholars Publishing, 241.

Jafary, J. (2000). Encyclopaedia of Tourism. Routledge, 307.

Latturinfo (2014). Rokasgrāmata tūrisma informācijas sniedzējiem, 19. 
Mayer, P., Pawlicz A. (2010). Financing tourist information service. Comparative study of West Pomerania province, Poland and lake Balaton, Hungary. Zeszyty Naukowe uniwersytetu Szczecinskiego. Ekonomiczne problem turystyki, 14 (592), 89-99.

Pechlaner, H., Volgger, M. and Herntrei, M. (2012). Destination management organizations as an interface between destination governance and corporate governance. An International Journal of Tourism and Hospitality Research, 23 (2), 151-168.

Smuškova, I. (2017). Tūrisms un likumi. Cik viegli un ērti strādāt jeb - vai likumdošana palīdz lauku tūrismam. Jurista vārds, 34 (988), 15-17. 